\title{
18
}

\section{The end of an era: Ronald Berndt and the German ethnographic tradition}

\author{
Nicolas Peterson ${ }^{1}$
}

In 1987, Ronald and Catherine Berndt (henceforth RMB and CHB) published a book titled End of an Era: Aboriginal labour in the Northern Territory. The core of the book was a report they had compiled of a survey of Aboriginal workers on pastoral stations in the Victoria River district of the Northern Territory in 1944-46. They chose the title not because there was any clear-cut break at that time but because it was evident in retrospect that the changes brought by the war, especially the experiences some Aboriginal people had working for the army in settlements along the Stuart Highway, foreshadowed the upsetting of the status quo (Berndt and Berndt 1987: xix). In fact, as far as the pastoral industry was concerned, it was another 20 years before there was a sharp break with the move to pay Aboriginal station workers full award wages, in 1965-68, bringing the regime of Aboriginal pastoral workers to an end. In the intervening period, the actions of the pastoralists had come under increasing surveillance.

1 This chapter has greatly benefited from detailed comments from John Stanton and a friendly if somewhat sceptical reading by Philip Jones, who, like Stanton, would place greater emphasis on the general ambience in which anthropology in Adelaide was carried out rather than on any specific German influence. 
Ironically, and completely unintended by the Berndts, their use of the phrase 'end of an era' could have applied equally well, at the time of publication of this book, to a book about their life and work. Although 1987 did not mark any specific break-RMB died on 2 May 1990 and CHB on 12 May 1994-the late 1980s saw the ongoing decline in Aboriginal ceremonial life, the details and complexity of which RMB, in particular, had made the focus of his ethnographic work. Together, the Berndts published over 40 monographs and edited books and more than 200 articles and papers: 14 books were jointly written, seven individually authored by $\mathrm{RMB}$, one ethnographic volume by $\mathrm{CHB}$ and four children's books, two jointly edited books and nine books edited by RMB, and then there are the numerous papers and chapters in books. RMB's seven single-authored books were monographs related to ritual and religion to which can be added a further seven more widely focused ethnographic publications authored jointly with CHB. This prodigious output is unlikely ever to be surpassed either in quantity or, more importantly, in its significance as ethnographic documentation of Aboriginal religion and classical Aboriginal societies and cultures more generally. It is a truly unique contribution.

In this chapter, I want to suggest that the uniqueness of this contribution to Australian anthropology owes something to RMB's German background and its influence, whether conscious or not, on his approach to ethnography and, one might say, in spite of his formal training in the discipline of anthropology. The significance of this suggestion is that it not only helps to identify the nature of RMB's lasting contribution, but also goes some way to explaining why his corpus has not had quite the influence it deserves but that it will surely gain in the future in respect of classical Aboriginal culture.

The Anglophone and Anglophile nature of Australian anthropology is not surprising despite the substantial number of German settlers, particularly in South Australia, or the number of German missionaries who worked with Aboriginal communities. As we have seen, much of the missionary work had a linguistic emphasis, because of the missionaries' background and training. However, it was the full-frontal attack by Sir Baldwin Spencer on the work of missionary Carl Strehlow (Kenny 2013: 1059) that helped entrench the divide between two styles of anthropology. On the one hand, there was the positivistic social evolutionary tradition of British anthropology giving way to the structural functionalist tradition from World War I, with its particular interest in social organisation, and, 
on the other hand, a more humanistic German tradition with its greater acceptance of the idea of culture in the plural and its greater focus on religion, mythology and language, giving rise to an ethnographic emphasis and especially interlinear texts. As I hope to show, RMB straddled these two traditions, but it is from the influence of the German tradition that the uniqueness and importance of his contribution stem.

\section{RMB's background and training}

RMB was born in Adelaide in 1916. His father's parents were both German speakers, but RMB himself neither read nor spoke German and, while his mother's father was of German-Huguenot background, his mother's mother was of Irish-Scots descent (Tonkinson and Howard 1990: 18). The family broke with the Lutheran Church and sent RMB to an Anglican school, Pultney Grammar. RMB was clearly bookish and did not share his father's interest in soccer, but he did share his father's passion for the study of other cultures and, together, they regularly visited the State Library and the South Australian Museum. His father also had a collection of Aboriginal artefacts and was an avid reader of 'ethnological' works (Tonkinson and Howard 1990: 20-1). Unfortunately, it is not known what books these were. ${ }^{2}$ By the age of 22 , RMB was subscribing to Oceania and, in 1939, he became an honorary assistant ethnologist at the South Australian Museum, publishing his first paper in the same year. In August of that year, he joined the 12-day Board for Anthropological Research's expedition to Ooldea as the social anthropologist, along with J. B. Cleland, T. Harvey Johnston, E. C. Black, F. Fenner and A. Harvey, as an assistant. Cleland and Johnston, along with C. P. Mountford, were to be his patrons in this early period (Jones 1987: 88). With the exception of Mountford, all these men had medical or scientific backgrounds. With the encouragement of Cleland and Johnston, RMB enrolled for a Diploma in Anthropology at the University of Sydney in 1940 under Professor A. P. Elkin, which required coursework and a short thesis (Berndt 1982b: 50; Gray 2005: 80). There he met Catherine, who had come to Sydney from New Zealand with a BA in Latin and French and a one-year undergraduate unit in anthropology from Dunedin.

2 This reading did include James Frazer (presumably, The Golden Bough) and A. C. Haddon (see Gray 2007: 159). 
In 1941, RMB published two papers, one with interlinear translation with Ted Vogelsang, the son of a missionary at Bethesda, who had an excellent command of Diyari (Berndt and Vogelsang 1941). By April 1941, RMB and CHB were married and on their way to Ooldea, funded by an Australian National Research Council grant for six months' research. In 1943, they both obtained their diplomas in anthropology; CHB graduated with an MA in anthropology in 1949 and RMB with a BA in 1950 and an MA in 1951, all from the University of Sydney. As is well known, Radcliffe-Brown, the father of structural functionalism, founded the Sydney department. From 1951 to 1953 (Berndt 1962a: xiv), the Berndts undertook pioneering fieldwork in the Eastern Highlands of New Guinea for which they both received their PhDs from the London School of Economics (LSE) in 1955.

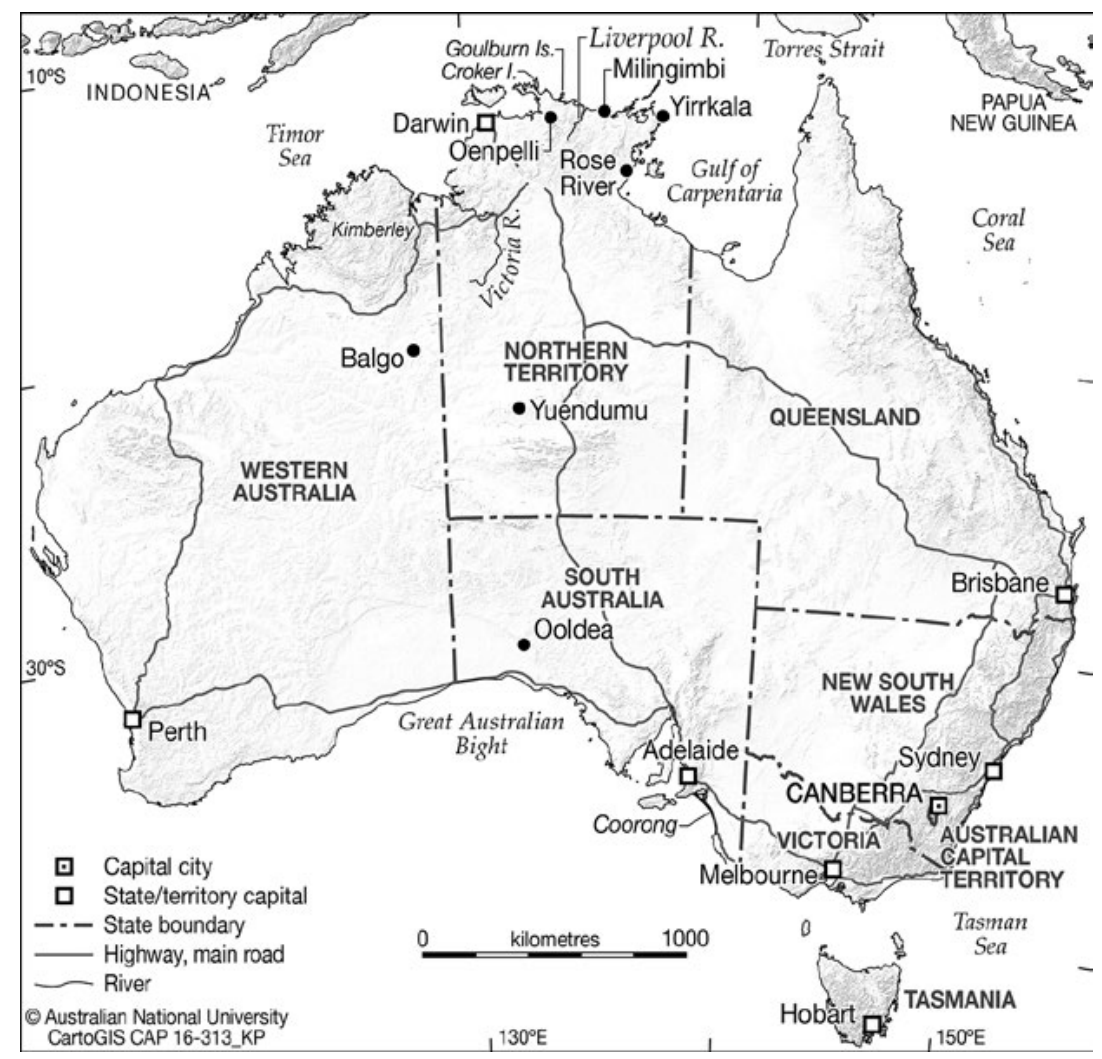

Map 18.1 Locations mentioned in the text.

Source: CartoGIS, The Australian National University. 
Thus, it can safely be said that the anthropological training that RMB and $\mathrm{CHB}$ received both in Sydney and at the LSE was firmly in the structuralfunctionalist tradition, although the teaching in Sydney was nothing like as narrow as it is often made out to be (see Berndt 1982b: 50-1). Raymond Firth, who had briefly held the chair at Sydney after Radcliffe-Brown's departure and was a core member of the structural-functionalist school, headed the department at the LSE (Kuper 1973: 156). Although Elkin's training in anthropology was in England, it was under G. Elliott-Smith and W. J. Perry, both of whom were diffusionists, with Elkin's own work focused particularly on social organisation in the structural-functionalist mode. However, RMB emphasises that once the Berndts had graduated:

we were virtually on our own. There was little direction on Elkin's part. He appreciated independence and initiative. What he expected from us was two-fold: doing research and writing up the results, and taking an active part in furthering his humanitarian interests. (Berndt 1982b: 51)

Although almost all RMB's and CHB's fieldwork was carried out jointly, there is no doubt that RMB dominated the partnership, as is reflected in the fact that he was always the senior author of their joint ethnographically based publications and the sole author of the seven ethnographically focused books, as opposed to Catherine's one. However, the fact that all their fieldwork was carried out collaboratively raises the question of the nature of their collaboration. In several places (e.g. Berndt and Berndt 1945: 3; Berndt 1976a: xx; 1982b: 62), the gendered division of labour in their fieldwork is emphasised, but, at the same time, RMB acknowledges CHB's assistance in preparing various volumes that appear under his name alone (Berndt 1976a: xx). It would require a detailed investigation - with access to their field notebooks, which are under an embargo until 2024, and drafts of manuscripts-to adequately unravel the exact nature of the collaboration.

\section{Early work}

The Ooldea Report was RMB and CHB's first book-length publication, appearing initially as articles across a number of issues of Oceania from 1942 to 1945 , and then reprinted as a monograph in 1945 . It is a wonderfully rich ethnography based on only six months' fieldwork, covering most aspects of Aboriginal life, including a 31-page article on language. It is a tribute to the intensity and systematic nature of their work. At the time they were in Ooldea, the population of from 80 to about 500 people was 
mobile, with 13 moves of various camps that were to be found within 2.5 kilometres of the soak (Berndt and Berndt 1945: 6). They strategically placed their own camp-known through their presence as the 'place of currants' - on the main pathway to the soak, but within hearing distance of the main camp so that they could be present there in a short time, and their camp became a stop-off point for people throughout the day (Berndt and Berndt 1945: 7). The monograph is organised around the male life cycle running from conception through initiation, marriage to death and the religious life. There are several striking things about the monograph: on page eight, they name 27 of their informants in the body of the text and record their indebtedness to them; the second of the 12 papers is devoted to the discussion of acculturation and applied issues, including some policy recommendations (Berndt and Berndt 1945: 27-46); an impressive 48 pages are devoted to magic; and 49 pages are devoted to women's lives.

They spell out in some detail their field methodology, which included observing a strict sexual division of labour (Berndt and Berndt 1945: 3):

\begin{abstract}
All information was recorded in a series of notebooks. Direct observations were noted in a rough book in pencil at the time and written up at the earliest opportunity so that no detail should be omitted. When recording either directly from an informant, or indirectly through interpreters, details of the discussion were written almost verbatim. Native texts were recorded in phonetic script word for word as spoken by the narrator, there being no interruptions till the end. Then the document was read out by the investigator each work translated and the actual native word checked. A discussion would then follow on the particular subject matter of the text and other problems that might arise would be noted for further questioning. Each evening the text, translation and discussion of the day would when possible be entered in the field note-book and comments made. We would then discuss between ourselves the data obtained in the day's work and so, by the constant scrutiny of material, errors or omissions could be discovered, and on further enquiry corrected and rectified. (Berndt and Berndt 1945: 9)
\end{abstract}

They state explicitly that their aim was 'to make a complete study of the Ooldea aboriginal culture' (Berndt and Berndt 1945: 3) that was a holistic functionalist account, and, in a general sense, this is what they achieved. At the end of the introductory paper, they spell out their general intellectual orientation to the work, under the heading 'The mythological basis of the desert culture': 
The myth is to these people a living reality believed to have once happened in the ancestral dream-times and to have brought about a social, moral and physical order. It dogmatizes on a 'way of life' ... Within the mythology is found an explanation of desert cult totemism and its associate rites, ceremonies, mysteries and mediations. It lays down a sacred rule, embracing not only the religious and moral aspects of desert society, but also the secular. It is sacred as well as profane, and is the axis upon which the culture of these desert people revolves.

By the above it is not to be thought that the whole of Ooldea life is mythologically bound; far from it. (Berndt and Berndt 1945: 25)

Although they did write about social organisation, the whole tenor of their first field project was its emphasis on empirical observation and the collection of texts, especially on mythology, and language.

In 1950, CHB published her MA thesis, Women's Changing Ceremonies in Northern Australia (Berndt 1950), based on work she had done between 1944 and 1946 in the Victoria River district. This provides descriptions of three kinds of women's ceremonies in the area: tjarada, jawalju (yawulyu) and an example of an individual women's ceremony. The monograph is structured around the question of what effect contact has had on these ceremonies and her conclusion is that while it had given them some slight impetus, the overall effect was deleterious (Berndt 1950: 9). The monograph, introduced by Lévi-Strauss, is identical in approach to the couple's Ooldea work and RMB's later writings, including considerable detail, interlinear song texts and a strong emphasis on sexual themes. Over the course of her academic career, $\mathrm{CHB}$ was to return to the issue of women's relation to the secret life (C. Berndt 1965) and status (C. Berndt 1970), but she also directed considerable energy to educating younger Australians about Aboriginal societies and cultures (e.g. C. Berndt 1979).

\section{The religious texts}

RMB's and CHB's publishing careers divide quite clearly into two periods: pre- and post-1962. Prior to 1962, they published all but one of their major ethnographic works, reflecting quite closely the enormous amount of time they spent in the field-almost continuously from 1941 to 1950 in Australia (see Berndt 1982a: 51-2, 54) and in New Guinea from 1951 to 1953 (Berndt 1962a: xiv)—and the rapidity with which they published core aspects of their research. After 1963, the emphasis 
was on edited volumes and more general works once RMB had taken on the responsibility of building up and running the Department of Anthropology at the University of Western Australia.

After the initial fieldwork in the desert at Ooldea, the regional focus of their work shifted to Arnhem Land and led to the publication of four monographs covering eastern Arnhem Land, three on western Arnhem Land and two with broad coverage. The best known is RMB's work An Adjustment Movement in Arnhem Land, Northern Territory of Australia (Berndt 1962a), which dealt with a hitherto unreported kind of movement that involved the deliberate revealing of previously secret objects to the general population.

There is no doubt, however, that the two books Kunapipi (Berndt 1951b) and Djanggawul (Berndt 1952) are the most significant works. ${ }^{3}$ These are extremely rich and highly specific accounts of two ceremonies held at that time in north-east Arnhem Land. While the Djanggawul ceremony relates to the dhuwa ngarra ceremony and was of long standing in the area, the Kunapipi ceremony was only just being introduced to the Yirrkala region at the time of the Berndts' fieldwork.

Kunapipi was RMB's first Arnhem Land ethnography. It benefited from his knowledge of the culture of the Victoria River district because it allowed him to see the wider regional connections of the ceremony-a point also emphasised in Elkin's introduction to the work. RMB sees the book as throwing new light on three aspects of Aboriginal religion (Berndt 1951b: xxvii): the concept of a fertility mother who is without totemic affiliation herself but who brought the totems into being; the relationship between the sacred and the profane, which he argues, contra Warner (1937), cannot be separated completely because each person has an 'individual germ' of the sacred or what he calls their 'own sacred aura'; and that women have a far greater part to play in sacred ceremonies than had been recognised before. Indeed, he argues, it is woman's unique ability to create life, together with man's power to inseminate, that has become a feature of Aboriginal religion in northern Australia (Berndt 1951b: xxviii). ${ }^{4}$ As he was to later repeat in other works, he sees the fundamental doctrine of these kinds of ceremonies as based on the 'essential human and animal drives of food

3 His original spelling for Djanggawul was Djanggewul (see Berndt 1952: 28). Ron and Catherine wrote Chapters 2-8 of Art in Arnhem Land and Elkin wrote Chapters 1 and 9 (Elkin et al. 1950: xi). 4 Phyllis Kaberry, in her book Aboriginal Women: Sacred and profane, published in 1939, had first challenged Warner's typification of women as only profane. 
and sex' (Berndt 1951b: 204, also p. 15). He states that the spread of cults such as the Kunapipi involved a certain amount of evangelisation by leaders interested in furthering the cult's activities (Berndt 1951b: xxix). In a rather obscure passage, he seems to suggest that the cults arise around individuals who become disguised as ancestral beings:

This aspect of individual origins, in relation to specific Australian Aboriginal cults, is an important one. The contention, which may be substantiated by mythology and the traditional song-cycles, is that a powerful personality - such as the Great Mother, the acknowledged spiritual leader and inspiration of the Kunapipi cult-possessed of ability beyond the ordinary, can and does exert his or her influence on the society in which he is either temporarily or permanently living; and that influence, helped by favourable circumstances, is sufficient to establish a cult which attracts adherents, and becomes in its own right an important social function and institution. (Berndt 1951b: xxviii)

From this, it is clear that RMB's understanding of the origin of this cult is not in sociological terms but in contingent historical terms, even though the documentation of other religious festivals with their implied sociopolitical functions was already explicit in the works of Spencer and Gillen (1899) and T. G. H. Strehlow (1947).

At the core of the Djanggawul book are the 188 (Berndt 1952: xxi) songs detailing the travels and activities of two ancestral sisters and their brother as they populated eastern Arnhem Land. These songs are unique in Australia for the extended narrative style of the verses-most of them at least 10 lines long and some up to 25-and for being in everyday language, yet poetic and evocative. Peter Toner ${ }^{5}$ has suggested that because the songs and their exegesis were recorded by writing, rather than by tape recorder, this method led to a more discursive style of transcription, which may in part account for the published features of this song cycle. However, John Stanton (2008) reports that the fieldnotes are word for word interlinear texts recorded by RMB and read back to the men for checking. The gloss on each section was, however, discursive text.

There is a high erotic content to the Djanggawul songs and mythology, as there is in the Kunapipi songs, leading RMB to feel it is necessary to counter the view that Aboriginal people are unduly concerned with the subject of sex 'and derive a morbid satisfaction from constant direct or symbolic reference to it' (Berndt 1952: 7). He goes on to say that 
Aboriginal people are frankly interested in the workings of the human body and in the satisfaction of its basic needs so that it is not unexpected to find manifestations of this interest in Aboriginal religious emblems and mythology, ritual and song. But he goes no further than this, basically eschewing any involvement with anthropological theory (e.g. Berndt 1952: $\mathrm{xx}, 10$ ), and concentrates on presenting the field data. ${ }^{6}$ From CHB, he learnt that women knew much information that is formally restricted to initiated men (Berndt 1952: 293). ${ }^{7}$

In addition to the above, RMB also collected three cycles of love songs at Yirrkala: the Goulburn Island cycle (dhuwa), the Rose River cycle (yirritja) and the Djarada. The first two cycles were in fact local creations but projected on to people elsewhere, and, by so doing, one might suggest, liberating their creative imagination (Berndt 1976a: xi, xviii). The third cycle was, however, definitely introduced. The book was not published until 1976, partly because RMB was 'not sure that its frankness and its erotic content would be appreciated by non-Aboriginal readers' (Berndt 1976a: xi). It is sobering to realise that by the 1960 s these songs were no longer remembered (Berndt 1976a: xix). When it came to publication, two versions were produced: a long version aimed at academics and an abridged version for the general public (Berndt 1976b).

RMB draws attention to the difference in attitude to sex between eastern and western Arnhem Land:

[W] estern Arnhem Landers who had seen the elaborate ritual which ordinarily accompanied traditional and public expressions of love in the north-eastern region, or those who had listened to one song after another and to the relatively indirect erotic references, wondered why it was necessary to spend so much time on extraneous matters when the sexual appetite could be assuaged much more easily and without such conventional preliminaries. Basically this is really a question of aesthetics. It could well be argued that if the sex object, and/or the whole erotic sequence for that matter, is to be attractive and desirable to those embarking upon such an experience, certain expectations must be fulfilled. (Berndt 1976a: xiv)

6 Sometimes one wonders about the empirical basis of these data, even when he acknowledges Catherine's help (Berndt 1952: xix), as when he comments that 'the clitorises of many Aboriginal women are fairly well developed' (p. 11).

7 From the Yirrkala area, Ron and Catherine moved west to Milingimbi, where they worked in 1946-47, recording a further 264 Djanggawul songs from which they prepared an unpublished volume called 'Daughters of the sun' (see Berndt 1952: xxi). 
This kind of comparison of regional cultural styles is not what would be expected from a structural-functionalist approach and is much closer to the sort of comment that might be expected from an American-trained anthropologist.

There is a marked contrast between RMB's work and that of Lloyd Warner, who also worked with the Yolngu in north-eastern Arnhem Land. While Warner does include some listing of song content in his very detailed descriptive account of the organisation of the Kunapipi and Djunggawan ceremonies, along with an account of the myths, there is no evidence to suggest that the song and mythological material are based on the collection of interlinear texts. Warner (1937) is concerned with social analysis under the heading of 'Absolute logics', discussing the ceremonies in the two chapters headed 'Murngin totemism' and 'An interpretation of Murngin totemism and of its ritual logics'. RMB comments in his conclusion to Djanggawul that, in reading through the mythology and songs:

it is possible for aliens such as ourselves to understand in some degree the fundamental issues involved in one Aboriginal religious cult. Moreover, it is only through the medium of such material, particularly in the form of interlinear translations, that we may attain more than a superficial understanding of Aboriginal thought and behaviour. These songs express what may be described as the spiritual quality of this particular Aboriginal society. (Berndt 1952: 292-3)

This emphasis is entirely consistent with the work carried out at Ooldea and not, as might be suggested, simply a reaction to the material published by Warner. RMB approached research with the Yolngu from a quite different angle, as becomes even more apparent in the light of the differences in approach to material culture, discussed in the next section.

The Berndts' work in western Arnhem Land continued with an emphasis on sexuality, leading to their monograph 'Sexual behaviour western Arnhem Land'. They write:

When they first worked in these areas, the writers were interested more in a general approach to the local culture, but as work was intensified they observed that the sexual element was stressed above all else. That is, they did not enter field-work here with pre-conceived ideas on the subject nor with the avowed intention of investigating only the sexual aspect. (Berndt and Berndt 1951b: 29) 
They comment in the introduction that the importance of sex has not been fully realised in Aboriginal anthropology and go on to say that it is 'only after the satisfaction of the bodily lusts of sex and eating that spiritual experience and growth can function smoothly and with some degree of expansion' (Berndt and Berndt 1951b: 15-16). They refer to Róheim's work but see this just in relation to mythology and ritual. In a footnote, they spell out their ideas a little further:

That is, unless sexual desire can be successfully sublimated and diverted into other channels (cf. the voluntary celibacy of certain religious orders). However, this does not occur in Australian aboriginal society; and in present-day European society sexual maladjustment is a contributing factor to emotional and social instability and unrest. (Berndt and Berndt 1951b: 15)

This seems to be the most explicit statement that is provided anywhere of their underlying thinking about the place of sex in society. The actual statement of what they call their thesis is, in contrast, based simply on a distinction between what they see as social and what they see as individual, with an emphasis on the former:

$[T]$ he sexual act and the accompanying erotic play are incidental and personal, while the events leading up to, surrounding or resulting from this subject, and the institutions involved, are of general social importance to the community. (Berndt and Berndt 1951b: 17, 242)

The strength of this book is the highly specific detail deriving from texts of conversations, myths and songs of several kinds-much of it, to put it in today's terms, about desire. They conclude:

The continual urge for sexual intercourse between men and women seems to be a primary consideration in Goulburn Island-Oenpelli-Liverpool society and receives far greater attention that the actual obtaining of and foraging for food. (Berndt and Berndt 1951b: 240)

Again, this does not read like a comment from the Sydney school. Typically, after 240 pages on the subject, they list some of the matter left out: the sexual life of widows and widowers, the ceremonies and restrictions that must precede remarriage and the sexual experience of people who have spent time in and near Darwin; no subject is ever exhausted.

Man, Land and Myth (Berndt and Berndt 1970), an ethnography of the Gunwinngu, is, by contrast, a much more holistic functionalist ethnography, written at a time of intellectual change in the discipline, 
which RMB saw as requiring the examination of ethnographic material in relation to specific problems (see below). ${ }^{8}$ Unlike in the earlier ethnographies, here consideration is given to some of the other Australianist literature as it relates to land tenure, social organisation and religion (see Berndt and Berndt 1970: 210-36), but this is only at the end of the book following a quite generalised ethnography-for instance, the section on Kunapipi is only three pages of text and the engagement with the literature is really quite brief, being no more than a checklist.

The final ethnography for this region is a short book, The Sacred Site: The western Arnhem Land example (R. Berndt 1970a). In a way, this follows from RMB's important paper 'The Gove dispute: The question of Australian Aboriginal land and the preservation of sacred sites' (R. Berndt 1964), in that, like the paper, the book is an extensive piece of coastal mapping - in this case, of Croker Island and the adjacent mainland. Together, these two works foreshadowed what is now commonplacemapping Aboriginal placenames-but which, surprisingly, was then a practice almost unknown among others working out of Sydney, but was the practice of Tindale and Mountford. Both were done at a distance and were greatly facilitated by being on the coast with its relatively easily identified features. Despite almost all of the sites being on the shore, or even in the sea, the analysis was entirely in respect of land, with nothing to say about sea estates. Nevertheless, these two studies were a major innovation, outside the published work done in either the German or the British tradition. Man, Land and Myth was the most mainstream of their ethnographies.

\section{The revelation of the later years}

The second book RMB published was titled Art in Arnhem Land, co-authored with Elkin and CHB (1950) and based on RMB's master's thesis. Although he later published three other books on the topic (Berndt 1964; Berndt and Phillips 1973; Berndt and Stanton 1980), as well as some important articles (see Berndt 1958), it was not widely understood until recently how strong RMB's interest in art was nor the magnificence of the collections he assembled. He made extensive collections not only

8 Although $A$ World that Was appeared in 1993, up to Chapter 10 had been written in 1943-44, but was rewritten before publication (Berndt and Berndt 1993: 11). Even so, the nature of this ethnography is little different from their other writings from the pre-1963 period. 
within Australia, but also privately of Asian art, the latter in conjunction with $\mathrm{CHB}$, and the existence of which was concealed largely for insurance and security purposes (Brittlebank 2008). Although he published on aspects of his Australian collections from early on, the 'crown jewels', as RMB referred to them (Stanton 2013: 18), were not widely seen until 2013. These are the 365 truly wonderful crayon drawings on brown paper from Yirrkala collected between 2 December 1946 and 28 June 1947 (Stanton 2013: 18-19). Although a few of them had been displayed in a 1995 exhibition and some had been published in the books on Arnhem Land, where they were virtually all in black and white and reduced from their large size (mostly $115 \times 74 \mathrm{~cm}$ ), losing much of their visual impact, it was not until a large selection was displayed at the Art Gallery of New South Wales that they started to receive wide attention (see Pinchbeck 2013). There is yet another set of crayon drawings from the northern Tanami Desert of which only tantalising glimpses have been given and which is yet to be published in its full glory (Stanton 2008: 520-2, 534; Berndt and Berndt 1950).

Along with 219 bark paintings, the Berndts collected a wide range of three-dimensional items of material culture from Arnhem Land. In a conversation with Peter Lauer, director of the anthropology museum at the University of Queensland, RMB comments:

Objects of all sorts abounded [in Arnhem Land]. They were part of the living culture, all of them in use. When I did commence to 'collect' there was nothing deliberate about it ... the paintings and carvings themselves were vivid expressions of social relations on one hand, clusters of meaning on the other. They gave an additional, tangible dimension to understanding particular mythological situations that were not really explicable through oral communication alone. Through visual depiction ... they created a multi dimensional ... 'vision' of mythic events set within their situational contexts. (Quoted in Stanton 2008: 514)

Here the emphasis is entirely on meaning rather than the way material culture and painting relate to social organisation that a more Durkheimian approach would have emphasised. Indeed, RMB went on to say that his collections were made at a time when it was:

popular among social anthropologists to denigrate the activities of museum ethnologists as not falling within the legitimate scope of what social anthropologists conceived to be their role on the field. (Quoted in C. Berndt 1979: 143) 
Reflecting on what influenced him in making basic western and eastern Arnhem Land collections of bark paintings and sculptures, RMB comments: 'For myself, perhaps having been an ethnologist before becoming a social anthropologist had something to do with my making' the collections, although he also says he was 'not consciously oriented in museum terms' (C. Berndt 1979: 144). Association with the South Australian Museum was undoubtedly an explicit influence in some areas, as it was from Mountford that he got the idea of collecting crayon drawings (C. Berndt 1979: 145).

\section{Conclusion}

It is, perhaps, the focus on religion and mythology and the commitment to producing interlinear texts of the songs so central to Aboriginal religions that give a German inflexion to RMB's work. This emphasis may have come from Tindale, who was keen on this technique, but it was certainly not from Elkin, even though he did produce a few interlinear texts based on attending a mardayn ceremony in 1949 (Elkin 1972), possibly influenced by RMB. RMB indicates that he had sought some informal linguistic training from Professor J. A. FitzHerbert at the University of Adelaide and used Noel-Armfield's (1924) Cambridge University Press publication on phonetics as his practical guide for transcription before his first fieldwork, with Albert Karloan and Pinky Mack at Murray Bridge between November 1939 and February 1940 (Berndt and Berndt 1993: 3, 10). He had no other training at that time (Berndt and Berndt 1993: 3) and started out writing down texts in English, gradually moving to using Yaralde-commenting in his introduction to $A$ World that Was that 'we place great value in the recording of interlinear texts, especially when a memory culture is concerned' (1993: 10). He also had the experience of collaborating with Ted Vogelsang in 1940 (Berndt and Vogelsang 1941) on the paper on Diyari medicine men in which they published interlinear texts.

In 1939, the only other ethnographers working in this mode were both from German backgrounds. Helmut Petri was here from Germany on the Frobenius Expedition in the Kimberley. He reports that a 'large part of my ethnographic fieldnotes fell victim to the bombing, in particular the original texts of the mythical traditions of the Ungarinyin with interlinear 
translation' (Petri 2011: 248). ${ }^{9}$ It is also relevant that the Berndts visited these anthropologists and Pater Wilhelm Schmidt (see Tonkinson and Howard 1990: 30) and Humbolt and Leipzig universities during their trips to Europe and maintained correspondence with many German anthropologists over the years. ${ }^{10}$

Ted Strehlow was another person with anthropological training and a native competence in Aranda, as well as English and German, who would have been an influence on RMB, as they were close personal friends. But, although Strehlow maintained a lifelong interest in Arandic ethnography, his academic disciplines were linguistics and literature. Interestingly, he did receive some limited anthropological training at the LSE from Raymond Firth, but it seems to have had little influence on him, not least I suspect because of his isolation from the mainstream of the discipline here; as Diane Austin-Broos reports (Chapter 9, this volume), neither Firth nor Elkin was really impressed with Strehlow's anthropology.

The linguistic aspect of RMB's work pre-dated his time at Sydney and meeting $\mathrm{CHB}$ and, despite Malinowski's emphasis on the need for ethnographers to learn the local language, language was never central to British anthropology in the same way that it was in Germany. Further, even before the department of anthropology he founded at the University of Western Australia in 1956 separated from the psychology department that provided it an initial home, RMB had appointed an anthropological linguist, Susan Kaldor, to his staff in 1961 to teach anthropological linguistics as an essential prerequisite for any research (R. Berndt 1979: 509). While Dr Arthur Capell, a linguist, was employed in a research position in the anthropology department at the University of Sydney, there was no such emphasis on anthropological linguistics in teaching there.

So, this raises the question of what relevance this possible influence of the German humanistic tradition on RMB's work has for understanding why this enormously valuable corpus has not had quite as much impact as one might expect.

A factor that has contributed to the undervaluing of RMB's work is his writing style, which lacks a certain clarity and is full of qualifications and deferrals, as others have also commented (e.g. see Morphy 2009). I do not

9 Tindale (1937) also published some limited interlinear song text material from the Coorong area. 10 John Stanton, personal communication. 
think, however, that this is an important reason. Much more significant, I think, is that RMB's explicit emphasis on placing ethnography before theory-indeed, largely ignoring theory (but see Berndt 1970b and 1974 especially) - makes for dense reading often attractive only to those with a specialised local interest. In RMB's first Arnhem Land monograph, Kunapipi, he states:

The whole question of Australian Aboriginal religion needs far more consideration than has been accorded it to date; but before any reliable theoretical studies can be made, it is essential that anthropological fieldworkers should provide considerably more data than are at present available. (Berndt 1951b: xxvi)

In the following year when he published his foundational work on Arnhem Land Aboriginal religion, Djanggawul, he wrote:

A considerable amount of thought has gone into the question of presenting the available data on the Djanggawul. It has finally been decided to present as much as possible of the 'raw' material without, apart from interpretation and partial analysis, engaging in theoretical discussion, for material of this type obviously lends itself to such treatment. It is our contention that the role of the anthropologist in the Australian Aboriginal field should be one of recording data, and of presenting these in an accessible form, so that the maximum amount of material may be available for the consideration of students interested primarily in theory. This is not to say that we disparage that particular branch of anthropological science, but that we ourselves are more intimately concerned with Australian Aboriginal problems ... we are acutely aware of the limitations of available anthropological data. (Berndt 1952: xx)

RMB never really moved from this position, although, by 1967 , it is possible to detect a slightly defensive tone when making the same point. ${ }^{11}$ In a paper presented at the 1966 general meeting of the Australian Institute of Aboriginal Studies (AIAS), as it then was, he comments:

The strength of Australian Anthropology lay in the emphasis that has been placed on empirical material rather than on the pretentious generalizing on an insufficient basis of fact which sometimes passes for theorizing. It is my belief that much of the ethnographic reporting which has taken place on this Continent, and the subsequent analysis of that material,

11 In the foreword to the 1985 edition of The World of the First Australians (see Berndt and Berndt 1988: xi), they are saying the same thing: 'it is important, in fact, imperative, to have a reasonably good grasp of the "facts" of a situation before theorizing about that situation.' 
will have currency in the future-which is more than can be said of a great deal of speculatory and fashionable 'theorizing for the sake of theorizing' produced elsewhere ... The down-grading of ethnography, the use of this word as a term of disparagement, can do only harm to our discipline.

Nevertheless, our emphasis must shift, as it has to some extent already done, to looking at our material in relation to specific problems rather than simply recording the ethnographic material. (Berndt 1967: 42)

For this emphasis on ethnography over theorising, he will be thanked by future generations. A greater emphasis on analysis would have thinned the ethnography, although, in so doing, it would probably have made it easier for non-specialists to approach. It would be wrong, however, to give the impression that RMB did not have any analytical or theoretical contributions to make. While his theoretical orientation when exercised was undoubtedly functionalist, as one would expect, his study in the New Guinea Highlands_Excess and Restraint: Social control among a New Guinea mountain people (Berndt 1962b)—where he and Catherine were only the second anthropologists to work, makes it clear, as Raymond Firth (1990: 5) points out, that functionalists did not only study societies in equilibrium. Indeed, this was already clear from the section on acculturation in the Ooldea report and from the Berndts' book on social change in South Australia (Berndt and Berndt 1951a). Among the more influential papers are 'Ceremonial exchange in western Arnhem Land' (Berndt 1951a), the synthetic paper on 'Law and order in Aboriginal Australia' (R. Berndt 1965) and his classic paper on 'The concept of the "tribe" in the Western Desert of Australia' (Berndt 1959)_all papers in the structural-functionalist mode.

What makes RMB's work the end of an era are the changes that have and are taking place in both the Aboriginal and the anthropological worlds. The impact of the full incorporation of Aboriginal people in remote Australia into the cash economy from the 1970s has had both positive and negative consequences. The most negative have been the over-involvement with alcohol, which, along with an increasingly poor diet, has had a catastrophic impact on life expectancy and physical health, affecting the ratio of knowledgeable elders to the rest of the population, and which has seen a substantial decline in religious life and many areas being swamped with the holding of mortuary rites. The internet, television and media more generally have become a focus for the younger generations at the expense of Aboriginal religion, to be replaced in some areas with a wide range of Christian sects. In Yuendumu, in the Northern Territory, this has 
gone from one to five between the 1970s and today. On the other hand, anthropology has been dominated by an applied focus mainly around land claims and native title from 1978 to the present (see Austin-Broos 2011). Other factors are important, too, including an increasing emphasis on restricting outsiders' access to ceremonial life. Although there have been many excellent theses produced in the past 25 years, social change, health, women's lives and so on have taken the focus away from religion and mythology.

However, a new era of German-influenced ethnography began with the twenty-first century; this time, it is associated not so much with a topical focus as with a theoretical approach. With the arrival of a small but steady stream of students trained in the German tradition, phenomenology has come to feature alongside concerns with structure, agency and power, now taken up by some students trained in Australia, infusing the discipline with a new and rich seam of ethnography (e.g. see Musharbash 2008; Eickelkamp 2001; Heil 2003; Kenny 2013).

Work today in the areas that were of central interest to RMB is much more in the nature of salvage ethnography than anything he could have imagined. I leave RMB with the last word about his interests and the reader to reflect on the differences with today:

'It was in the sphere of religion, however, that I personally found greater satisfaction [than work in other areas] ... particularly song-poetry' (1982: 55), going on to say that, 'Intellectually, the field of religion in its broadest sense offers perhaps the most rewarding area for continued investigation. This is because it is relevant to most of the features I have referred to [social organisation and social control], and because it concerns varying forms of aesthetic expression — myth and oral literature generally, song-poetry and music, ritual and dramatic performance, visual representations and art. (Berndt 1982b: 61)

\section{References}

Austin-Broos, D. 2011. A Different Inequality: The politics of debate about remote Aboriginal Australia. Sydney: Allen \& Unwin.

Berndt, C. 1950. Women's Changing Ceremonies in Northern Australia. Cahiers D'Ethnologie, de geographie et de linguistique No. 1. Paris: Hermann. 
Berndt, C. 1965. Women and the 'secret life'. In Aboriginal Man in Australia: Essays in honour of Emeritus Professor A. P. Elkin, (eds) R. Berndt and C. Berndt, pp. 238-82. Sydney: Angus \& Robertson.

Berndt, C. 1970. Digging sticks and spears, or, the two-sex model. In Woman's Role in Aboriginal Society, (ed.) F. Gale, pp. 29-50. Canberra: Australian Institute of Aboriginal Studies.

Berndt, C. 1979. Land of the Rainbow Snake. Arranged and translated with illustrations by D. Yunupingu. Sydney: Collins.

Berndt, C. and Berndt, R. 1971. The Barbarians: An anthropological view. London: C. A. Watts.

Berndt, C. and Berndt, R. 1978. Pioneers and Settlers: The Aboriginal Australians. Melbourne: Pitman.

Berndt, R. 1948. A Wonguri-Mandjigai song cycle of the moon-bone. Oceania 19(1): 16-50. doi.org/10.1002/j.1834-4461.1948.tb00493.x.

Berndt, R. 1951a. Ceremonial exchange in western Arnhem Land. Southwestern Journal of Anthropology 7(2): 156-76. doi.org/10.1086/ soutjanth.7.2.3628621.

Berndt, R. 1951b. Kunapipi: A study of an Australian Aboriginal religious cult. Melbourne: Cheshire.

Berndt, R. 1952. Djanggawul: An Aboriginal religious cult of north-eastern Arnhem Land. London: Routledge \& Kegan Paul.

Berndt, R. 1955. 'Murngin' (Wulumba) social organization. American Anthropologist 57(1): 84-106. doi.org/10.1525/aa.1955.57. $1.02 \mathrm{a} 00100$.

Berndt, R. 1957. In reply to Radcliffe-Brown on Australian local organization. American Anthropologist 59: 346-51. doi.org/10.1525/ aa.1957.59.2.02a00180.

Berndt, R. 1958. Some methodological considerations in the study of Australian Aboriginal art. Oceania 29(1): 26-43. doi.org/10.1002/ j.1834-4461.1958.tb02935.x. 
Berndt, R. 1959. The concept of the 'tribe' in the Western Desert of Australia. Oceania 30(2): 81-107. doi.org/10.1002/j.18344461.1959.tb00213.x.

Berndt, R. 1962a. An Adjustment Movement in Arnhem Land, Northern Territory of Australia. Paris: Mouton.

Berndt, R. 1962b. Excess and Restraint: Social control among a New Guinea mountain people. Chicago: Chicago University Press.

Berndt, R. 1964. The Gove dispute: The question of Australian Aboriginal land and the preservation of sacred sites. Anthropological Forum 1(2): 258-95. doi.org/10.1080/00664677.1964.9967198.

Berndt, R. 1965. Law and order in Aboriginal Australia. In Aboriginal Man in Australia: Essays in honour of Emeritus Professor A. P. Elkin, (eds) R. Berndt and C. Berndt, pp. 167-206. Sydney: Angus \& Robertson.

Berndt, R. 1967. The next phase of anthropological research in Australia. Australian Institute of Aboriginal Studies Newsletter 2(5): 42-52.

Berndt, R. (ed.). 1969. Thinking about Australian Aboriginal Welfare with Particular Reference to Western Australia. Perth: University of Western Australia Press.

Berndt, R. 1970a. The Sacred Site: The western Arnhem Land example. Canberra: Australian Institute of Aboriginal Studies.

Berndt, R. 1970b. Traditional morality as expressed through the medium of a Australian Aboriginal religion. In Australian Aboriginal Anthropology, (ed.) R. Berndt, pp. 216-47. Perth: University of Western Australia Press.

Berndt, R. 1974. Australian Aboriginal Religion (in Four Fascicles). Leiden: Brill for the Institute of Religious Iconography, State University of Groningen.

Berndt, R. 1976a. Love Songs of Arnhem Land. Melbourne: Nelson.

Berndt, R. 1976b. Three Faces of Love: Traditional Aboriginal song-poetry. Melbourne: Nelson.

Berndt, R. (ed.). 1977. Aborigines and Change: Australia in the '70s. Canberra: Australian Institute of Aboriginal Studies. 
Berndt, R. 1979. Aboriginal studies within the Department of Anthropology, University of Western Australia. In Aborigines of the West: Their past and their present, (eds) R. M. Berndt and C. H. Berndt, pp. 509-16. Perth: University of Western Australia Press.

Berndt, R. (ed.). 1982a. Aboriginal Sites, Rights and Resource Development. Perth: University of Western Australia Press.

Berndt, R. 1982b. The changing face of Aboriginal studies: Some personal glimpses. In Anthropology in Australia: Essays to honour 50 years of 'Mankind', (ed.) G. McCall, pp. 49-63. Sydney: Anthropological Society of New South Wales.

Berndt, R. and Berndt, C. 1945. A Preliminary Report of Field Work in the Ooldea Region, Western South Australia. Sydney: Oceania Publications.

Berndt, R. and Berndt, C. 1950. Aboriginal art in central-western Northern Territory. Meanjin 9(3): 183-8.

Berndt, R. and Berndt, C. 1951a. From Black to White in South Australia. Melbourne: Cheshire.

Berndt, R. and Berndt, C. 1951b. Sexual Behaviour in Western Arnhem Land. New York: The Viking Fund.

Berndt, R. and Berndt, C. 1954. Arnhem Land: Its history and its people. Melbourne: Cheshire.

Berndt, R. and Berndt, C. 1970. Man, Land and Myth: The Gunwinggu people. Sydney: Ure Smith.

Berndt, R. and Berndt, C. 1987. End of an Era: Aboriginal labour in the Northern Territory. Canberra: Australian Institute of Aboriginal Studies.

Berndt, R. and Berndt, C. 1988. The World of the First Australians: Aboriginal traditional life past and present. 4th rev. edn. Canberra: Aboriginal Studies Press.

Berndt, R. and Berndt, C. 1989. The Speaking Land: Myth and story in Aboriginal Australia. Melbourne: Penguin Books. 
Berndt, R. and Berndt, C. 1990. A select bibliography. In Going it Alone? Prospects for Aboriginal autonomy: Essays in honour of Ronald and Catherine Berndt, (eds) R. Tonkinson and M. Howard, pp. 45-63. Canberra: Aboriginal Studies Press.

Berndt, R. and Berndt, C. 1993. A World that Was: The Yaraldi of the Murray River and the lakes, South Australia. Melbourne: Miegunyah Press.

Berndt, R. and Phillips, E. (eds). 1973. The Australian Aboriginal Heritage. Sydney: Ure Smith.

Berndt, R. and Stanton, J. 1980. Australian Aboriginal Art. Perth: University of Western Australia Press.

Berndt, R. and Vogelsang, T. 1941. The initiation of native-doctors, Dieri tribe, South Australia. Records of the South Australian Museum 6(4): 369-80.

Brittlebank, K. 2008. Two people, one life. Australian Historical Studies 39: 3-18. doi.org/10.1080/10314610701837201.

Eickelkamp, U. 2001. Pitjantjatjara women's art at Ernabella: Genesis and transformation. Unpublished $\mathrm{PhD}$ thesis. Heidelberg University, Heidelberg.

Elkin, A. 1972. Two rituals in south and central Arnhem Land. Oceania Monographs No. 19. University of Sydney, Sydney.

Elkin, A., Berndt, C. and Berndt, R. 1950. Art in Arnhem Land. Chicago: Chicago University Press.

Firth, R. 1990. The Berndts: An overview. In Going it Alone? Prospects for Aboriginal autonomy: Essays in honour of Ronald and Catherine Berndt, (eds) R. Tonkinson and M. Howard, pp. 3-9. Canberra: Aboriginal Studies Press.

Gale, F. 1972. Urban Aborigines. Canberra: ANU Press.

Gray, G. 2005. 'You are ... my anthropological children': A. P. Elkin, Ronald Berndt and Catherine Berndt, 1940-1956. Aboriginal History 29: 77-106. 
Gray, G. 2007. Cluttering up the department: Ronald Berndt and the distribution of the University of Sydney ethnographic collection. Recollections: Journal of the National Museum of Australia 2(2): 153-79.

Heil, D. 2003. Well-being and bodies in trouble: Situating health practices within Australian Aboriginal socialities. Unpublished PhD thesis. University of Sydney, Sydney.

Jones, P. 1987. South Australian anthropological history: The Board for Anthropological Research and its early expeditions. Records of the South Australian Museum 20: 71-92.

Kaberry, P. 1939. Aboriginal Woman: Sacred and profane. London: Routledge.

Kenny, A. 2013. The Aranda's Pepa: An introduction to Carl Strehlow's masterpiece Die Aranda- und Loritja-stämme in Zentral-Australien (1907-1920). Canberra: ANU E Press.

Kuper, A. 1973. Anthropologists and Anthropology: The British school 1922-1972. London: Penguin Books.

Morphy, H. 2009. Re-reading Ronald Berndt: Exploring the depths of his Yolngu ethnography. Anthropological Forum 19(1): 73-97. doi.org/10.1080/00664670802695624.

Musharbash, Y. 2008. Yuendumu Everyday. Canberra: Aboriginal Studies Press.

Noel-Armfield, G. 1924. General Phonetics for Missionaries and Students of Languages, 3rd edn. Cambridge: W. Heffer \& Sons.

Petri, H. 2011 [1954]. The Dying World in Northwest Australia. English trans. Perth: Hesperian Press.

Pinchbeck, C. (ed.). 2013. Yirrkala Drawings. Sydney: Art Gallery of New South Wales in association with the University of Western Australia.

Radcliffe-Brown, A. R. 1956. On Australian local organization. American Anthropologist58(2):363-7.doi.org/10.1525/aa.1956.58.2.02a00140.

Róheim, G. 1945. The Eternal Ones of the Dream: A psychoanalytic interpretation of Australian myth and ritual. New York: International Universities Press. 
Spencer, W. and Gillen, F. 1899. The Native Tribes of Central Australia. London: Macmillan.

Stanton. J. 2008. 'I did not set out to make a collection': The Ronald and Catherine Berndt collection at the Berndt Museum of Anthropology. In The Makers and Making of Indigenous Australian Museum Collections, (eds) N. Peterson, L. Allen and L. Hamby, pp. 511-36. Melbourne: Melbourne University Press.

Stanton, J. 2013. The crown jewels of our collection: The Yirrkala crayon drawings. In Yirrkala Drawings, (ed.) C. Pinchbeck, pp. 17-19. Sydney: Art Gallery of New South Wales in association with the University of Western Australia.

Strehlow, T. G. H. 1947. Aranda Traditions. Melbourne: Melbourne University Press.

Tindale, N. 1937. Native songs of the south-east of South Australia. Transactions of the Royal Society of South Australia 61: 107-20.

Tonkinson, R. and Howard, M. 1990. The Berndts: A biographical sketch. In Going it Alone? Prospects for Aboriginal autonomy: Essays in honour of Ronald and Catherine Berndt, (eds) R. Tonkinson and M. Howard, pp. 17-42. Canberra: Aboriginal Studies Press.

Warner, L. 1937. A Black Civilization. New York: Harper Brothers. 
This text is taken from German Ethnography in Australia, edited by Nicolas Peterson and Anna Kenny, published 2017 by ANU Press, The Australian National University, Canberra, Australia.

dx.doi.org/10.22459/GEA.09.2017.18 